\title{
The Influence of Impulsiveness on Local Food Purchase Behavior in a Tourism Context
}

\section{Abstract}

People show different purchasing behavior during travel than in their daily lives. During vacation, due to time limitations tourists tend to purchase local products impulsively. The current study aimed to incorporate impulsiveness in the Theory of Reasoned Action in a tourism context. The conceptual model assumes the direct influence of impulsiveness on the intention to eat local food and the food related behavior. We have also tested the moderating impact of impulsiveness on the relationship between affective attitude and intention. We have collected 380 questionnaires among visitors in South Carolina, USA and analyzed the results with Structural Equation Modelling (SEM). While the impact of impulsiveness on intention and behavior was not significant, the indirect influence of impulsiveness on the relationship between positive attitude and intention was. Current study showed the importance of positive attitude on the local food consumption among tourists. Study also revealed that impulsive people tend to act on positive thoughts and emotions. The promotional efforts to sell local food in the region should aim to strengthen positive emotions and encourage impulse purchase among tourists.

Keywords: impulsiveness, Theory of Reasoned Action, emotions, local food, intention, South Carolina

\section{Introduction}

Theory of Reasoned Action (TRA) has received attention from scholars in different disciplines including tourism for decades. The theory assumes that affect, cognition, and conation are the main antecedents of the behavior (Fishbein \& Ajzen, 1975). The application of TRA in tourism studies is seen mainly in the context of destination management. As such, the main aim of these studies is to understand the importance of attitude in determining the decision to visit a destination and its influence on the destination choice (Baloglu \&Brinberg, 1997; Kim \& Yoon, 2003). The destination choice is a pre-trip decision; therefore, in studies investigating destination choice the focus is on the pre-trip behavior of tourists. On the other hand, there are some decisions taken during the trip, such as food choice. Research shows that people tend to show impulsive purchase behavior for low-cost items (Beatty \& Ferrell, 1998; Youn \& Faber, 2000). In a travel budget, food cost is usually lower than other expenses such as accommodation and transportation. Also, due to its experiential nature, food has the potential to lead impulse purchases. Impulse purchase occurs as a result of affect (Miao, 2011), and since food appeals to five senses, there is a high possibility of buying food impulsively. Especially during a vacation, tourists are exposed to local food constantly. Therefore, they feel the pressure of tasting some food items that are unique to the area. The limitation of time also adds some more pressure which eventually lead to impulse purchases of unique local food. The current study investigates impulsiveness as an antecedent of intention and behavior in a tourism context.

The literature on impulsiveness in food shopping behavior is limited to daily food purchases (e.g. Chung et al., 2017; Duarte et al., 2013; Su \& Lu, 2018) and the previous research focusing on impulse buying in

Guliz Coskun, PhD, Corresponding author, Assistant professor, Department of Recreation Management, Faculty of Tourism, Sakarya University of Applied Sciences, Sakarya, Turkey; ORCID ID: https://orcid.org/0000-0002-5200-6370; e-mail: gcoskun@clemson.edu

William Norman, PhD, Professor, Clemson University, College of Behavioral Social and Health Sciences, Faculty of Parks Recreation and Tourism Management, Clemson, South Carolina, USA; ORCID ID: https://orcid.org/0000-0001-7447-360X; e-mail: wnorman@clemson.edu 
tourism is limited to online shopping (e.g Chih et al., 2012; Chen et al., 2019), general purchases (e.g. Li et al., 2015; Meng et al., 2019; Sohn \& Lee, 2017) and non-empirical studies (e.g. Ahn et al., 2019). Current study aims to fill this gap by testing the influence of impulsiveness on food shopping behavior among tourists.

Since the focus is only on tourist behavior during travel, the main interest will be on local food decisions. Local food is always attractive for tourists. As a part of a larger project (Jodice et al., 2015) current study was conducted in coastal areas of South Carolina. Oysters are locally harvested in South Carolina, and the region is well known for its high-quality oysters. Therefore, researchers have selected oysters to represent local food in the region. The study aims to test the influence of attitude and impulsiveness on the intention to purchase local oysters and local food purchase behavior during travel.

In the following sections literature review, method, results, discussion, limitations, suggestions for future research and conclusions will be discussed. Literature review is composed of two parts; Theory of Reasoned Action and impulsiveness. It also includes conceptual framework and research hypotheses. Method section has three parts; data collection, questionnaire design and reliability and validity of the data. The results section which includes demographic information and testing of hypotheses will be followed by discussion and implication section. Lastly, limitations and suggestion for future research will be discusses.

\section{Literature review}

\subsection{Theory of Reasoned Action}

Fishbein and Ajzen (1975) have conceptualized the TRA more than four decades ago. While affective attitude is formed as a result of emotions towards a product, cognitive attitude is based on thoughts. The third variable that influences behavior is conation, which is the intent to perform a behavior. The theory assumes, affective and cognitive attitude has an influence on intention, and intention has an influence on behavior. The theory, which has eventually evolved into the Theory of Planned Behavior (Ajzen, 1985), has received attention from many scholars in various disciplines. Many scholars used the TRA and Theory of Planned Behavior to understand food consumption decisions. However, the majority of these studies focus on daily food consumption and food consumption in a restaurant setting.

Previous research showed the significant influence of positive attitude towards food on the intention to purchase food among organic food consumers (Effendi et al., 2015) as well as multi-cultural fast food consumers (Bagozzi et al., 2000). A study conducted among restaurant customers revealed that while both cognitive and affective attitude has a significant impact on healthy eating behavior, affective attitude is a stronger predictor than cognitive attitude (Jun \& Arendt, 2016). This result is not surprising, as, in a restaurant setting, the service environment is as important as the food itself while choosing a menu item. On the other hand, some researchers who focused on daily food consumption have reached similar results. They have observed the significant influence of emotions on food and beverage consumption both consciously (Letarte et al., 1997; Uehara \& Assarut, 2020) and unconsciously (Winkielman et al., 2005). A study among French-Canadian adults revealed the origins of food likes are affective, explicitly based on emotions (Letarte et al.,1997). The impact of unconscious affective reactions on the consumption of unfamiliar beverage was found in an experimental study in which people were showed angry versus happy faces before they consumed the beverage. The people who were exposed to happy faces tend to consume more and have higher willingness to pay for the product (Winkielman et al., 2005). Trendel and Werle (2016) investigated the influence of cognitive and affective bases of implicit associations toward food. Results showed that affective associations are significant predictors of food choice only when cognitive associations are limited. 


\subsection{Food consumption while traveling}

The influence of cognitive and affective attitude on purchase behavior depends on the type of the food. Cognitive attitude is influential while purchasing functional foods, and affective attitude is more important in the consumption of pleasure foods (Žeželj et al., 2012). According to Lovelock (2004), tourists are becoming more creative and they are in need of an interactive experience during travel. Consumption of food is an interactive process in tourism experience and it has a power to create ties and build a sense of belongingness. Therefore, eating during travel is more than meeting a physiological need, it is a pleasurable activity. Hedonic trait of a product was found to have a significant impact on impulse purchase among Chinese long haul travellers (Meg et al., 2019). Food is an important part of a travel that offers hedonic experience.

Previous research focusing on food consumption while traveling has revealed intangible aspects of local food are as important as tangible aspects for tourists while making food choices (Kim et al., 2013; Ryu \& Han, 2010). A study conducted among food festival visitors, showed learning, fun and new experience are some important factors as well as quality and variety influencing local food consumption while traveling (Kim et al., 2010). According to Quan and Wang (2004) other factors influencing food consumption while traveling is memorability and novelty seeking behaviour. Local food has a potential to offer a memorable and novel experience that tourists are looking for. In their cross-cultural study among tourists visiting South Korea, Kim et al. (2013) showed that the motivational factors influencing food consumption while traveling are both cognitive such as sensory appeal and health concern and affective, such as cultural experience, excitement, and interpersonal relationship. Another study among tourists (Ryu \& Han, 2010) supported the significant positive effect of attitude on the intention to eat local food during travel.

As a result, both cognitive and affective attitude have an influence on the food choices among tourists. As it is shown on the conceptual model, the first sets of hypotheses are as follows (Figure 1):

- H1: Positive Cognitive Attitude is directly and positively related to intention to eat local food.

- H2: Negative Cognitive Attitude is directly and negatively related to the intention to eat local food.

- H3: Positive Affective Attitude is directly and positively related to the intention to eat local food.

- H4: Negative Affective Attitude is directly and negatively related to the intention to eat local food.

- H5: Intention to eat local food is directly and positively related to local food eating behavior.

\subsection{Consumer impulsiveness}

Stern (1962) defines impulse buying as 'any purchase which a shopper makes but has not planned in advance' (p. 59). There are some internal and external factors influencing impulse purchases, such as time limitations, atmosphere, personality trait, positive emotions and the scarcity of the products (Ahn et al., 2019; Dittmar et al., 1995; Lim \& Yazdanifard, 2015; Su \& Lu, 2018). The travel activity offers rather a distinct shopping environment compared to daily life. The pressure of time limitations and the scarcity of local products may lead tourists to purchase impulsively. According to Rook (1987), impulse buying is hedonic and emotional. Travel is an intangible product, which is an accumulation of experience that is based on emotions. Previous research showed that both positive and negative emotions play a role in impulse purchases (Beatty \& Ferrell, 1998; Sohn \& Lee, 2017; Tariq et al., 2019).

There is a limited number of studies focusing on impulse purchase behavior of tourists, as well as pleasure food consumption while travelling (Fusté-Forné, 2019). Ahn et al. (2019) listed the antecedents of impulse purchase among tourists as experiences, emotions, and individual characteristics. They also claimed that among all variables the pleasure has the strongest effect on impulse buying. The positive experience that tourists gain from the involvement of the product leads to impulsive purchase decisions ( $\mathrm{Li}$ et al., 2015). Furthermore, a 
study among duty free shoppers showed that positive emotions have a stronger impact than negative ones on impulse buying (Sohn \& Lee, 2017). A study among Taiwanese online shoppers showed that positive affect has significant influence on impulse buying behavior (Chih et al., 2012). Some authors have reached similar results regarding organic food purchase (Tariq et al., 2019).

The impulse purchase of products with lower financial value is more common. Compared to the other expense such as accommodation and transportation, food cost is relatively low for travelers. Previous research suggests that serendipity and scarcity of a product lead to higher impulse purchases (Chung et al., 2017). Therefore, the urge to taste unique local food will lead tourists to make food purchases impulsively during travel. Another factor influencing impulse purchase is the nature of product. People buy pleasure food, such as chocolate, more impulsively (Dubé et al., 2003). Since excitement is one of the motivations to taste local food during travel, tourists will perceive tasting local food as a pleasurable activity rather than satisfying their hunger (Kim et al., 2013). Dining environment has an influence on impulse buying in a restaurant setting (Su \& Lu, 2018). The change of dining environment during travel may lead tourists to engage in impulse food purchase.

Figure 1

Conceptual framework

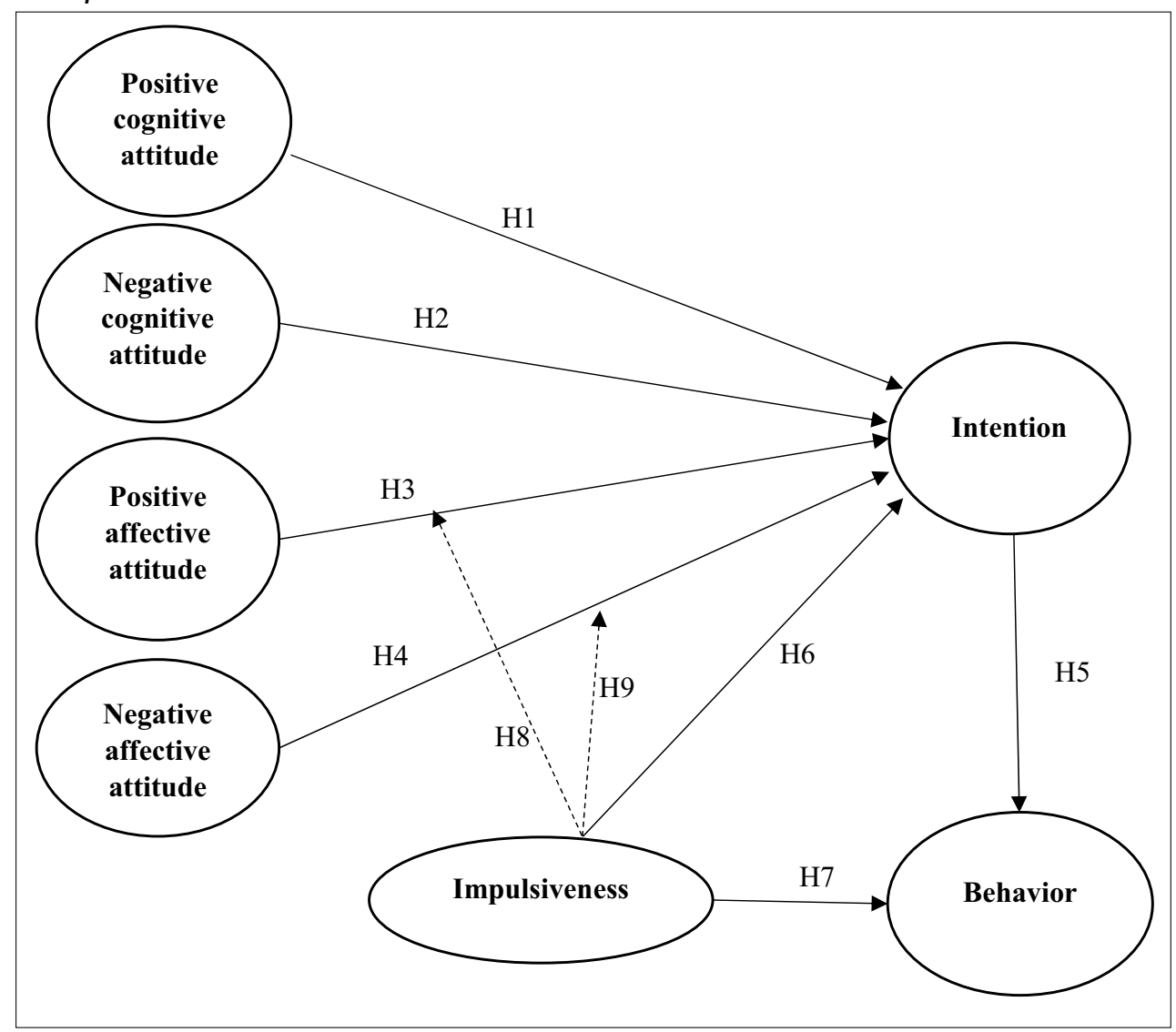

The purpose of this study is to analyze the influence of attitude and impulsiveness on the intention to eat local food and food related behavior during travel. The conceptual model assumes that the moderating impact of impulsiveness will only be significant on the relationship between affective attitude and intention, as previous research suggests that impulse buying occurs as a consequence of emotions (Rook, 1987; Beatty \& Ferrell, 1998; Miao, 2011). Based on the literature, the research hypotheses are as follows (figure 1): 
- H6: Impulsiveness is directly and positively related to intention to eat local food.

- H7: Impulsiveness is directly and positively related to local food eating behavior.

- H8: Impulsiveness moderates the relationship between positive affective attitude and intention.

- H9: Impulsiveness moderates the relationship between negative affective attitude and intention.

The conceptual framework of this study was based on the TRA (Figure 1). The aim of the model was to test the relationship between cognitive and affective attitude towards local seafood, impulsiveness, purchase intention of tourists and purchase behaviour. The model proposes a direct impact of cognitive and affective attitude on the on purchase intention. Also, moderating impact of impulsiveness on the relationship between affective attitude and local seafood purchase intention was proposed. The model also assumes the direct influence of intention and impulsiveness on the purchase behaviour.

\section{Method}

\subsection{Data collection}

The data were collected in the southeast part of the USA, where local seafood is available. In Charleston and Beaufort, oysters are a popular local seafood, which is available both farm-raised and wild-caught. Current research is conducted as a part of a larger study investigating the local food shopping behavior among couples visiting South Carolina (Coskun et al., 2019). Therefore, the data was collected from couples while they were travelling in Charleston and Beaufort. Researchers made sure each member of the couple eat oyster and both members were over 18. Stratified sampling was used for the study. The percentage of responses collected in each county represents the tourism expenditure of that county. Charleston County accounts for $63 \%$ percent and Beaufort county $37 \%$ of the total expenditure in both counties. As a result, researchers have obtained 380 questionnaires in total 240 (63\%) from Charleston and 140 (37\%) from Beaufort.

\subsection{Questionnaire design}

To measure cognitive and affective attitude, the scales prepared by Crites et al. (1994) was used. A onedimensional, nine-item scale developed by Rook and Fisher (1995) was used to measure impulsiveness. Lastly, to measure local food purchase intention, the scales developed by Blanchard et al. (2008), Bredahl (2001), and Robinson and Smith (2002) were used. To measure behavior, respondents were asked if they have eaten oysters in this trip.

\subsection{Reliability and validity of the data}

SPSS 21 was used to calculate Mahalanobis distance in order to assess the normality of the data (40 cases were deleted due to normality issues and missing cases). By using EQS 6.2 Structural Equation Modelling (SEM) was used to analyze the remaining 340 cases. Since the study aimed to test the moderating impact of impulsiveness on the relationship between affective attitude and intention, interaction variables were calculated. To test the reliability and the validity of the data the measurement model was run with all variables including interaction variables. The measurement model showed acceptable fit indices (Satora Bentler $\chi 2=714.845$, $\mathrm{df}=505, \mathrm{CFI}=.924$, RMSEA=.035). The factor loadings and AVEs were all over .6 and all AVEs are higher than squared factor correlations. The alpha and composite reliability range between .7 to .9. The reliability and validity of the data was established (Fornell \& Larcker, 1988). Table 1 displays the factor loadings, alpha and composite reliability of all variables. Table 2 shows AVEs and squared factor correlations of all variables. 
Table 1

Factor loadings, Cronbach's alpha and composite reliability for all items

\begin{tabular}{|c|c|c|c|}
\hline & Loadings & Alpha & $\begin{array}{l}\text { Composite } \\
\text { reliability }\end{array}$ \\
\hline P. Cognitive attitude & & .895 & .706 \\
\hline Good for health & .898 & & \\
\hline Safe & .832 & & \\
\hline Nutritious & .853 & & \\
\hline N. Cognitive attitude & & .907 & .718 \\
\hline Harmful & .868 & & \\
\hline Unsafe & .906 & & \\
\hline Not nutritious & .616 & & \\
\hline P. Affective attitude & & .974 & .913 \\
\hline Delighted & .961 & & \\
\hline Happy & .978 & & \\
\hline Excited & .928 & & \\
\hline Satisfied & .939 & & \\
\hline N. Affective attitude & & .969 & .907 \\
\hline Annoyed & .917 & & \\
\hline Bored & .958 & & \\
\hline Tense & .973 & & \\
\hline Sick & .921 & & \\
\hline Impulsiveness & & .903 & .904 \\
\hline 'Just do it' describe the way I buy things & .764 & & \\
\hline I often buy things without thinking & .865 & & \\
\hline 'I see it I buy it' describes me & .870 & & \\
\hline 'Buy now think about it later' describes me & .840 & & \\
\hline I buy things according to how I feel at the moment & 699 & & \\
\hline Intention & & .971 & .786 \\
\hline I have intended to eat & .966 & & \\
\hline I would likely eat & .973 & & \\
\hline I have planned to eat & .931 & & \\
\hline P. Affective attitude* impulsiveness & & .909 & .720 \\
\hline Happy* I often buy things... & .860 & & \\
\hline Excited * 'I see it I buy it' & .895 & & \\
\hline Satisfied* 'buy now think later'.. & .879 & & \\
\hline N. Affective attitude* impulsiveness & & .915 & .727 \\
\hline Bored* I often buy things... & .861 & & \\
\hline Tense* 'I see it I buy it' & .928 & & \\
\hline Sick* 'buy now think later'... & .867 & & \\
\hline
\end{tabular}

Notes: $\mathrm{P}=$ Positive, $\mathrm{N}=$ Negative

Table 2

AVEs and squared factor correlations

\begin{tabular}{l|c|c|c|c|c|c}
\hline & Poscog & Negcog & Posaft & Negaft & $\begin{array}{c}\text { Inten- } \\
\text { tion }\end{array}$ & $\begin{array}{c}\text { Impul- } \\
\text { siveness }\end{array}$ \\
\hline Poscog & $.742^{1}$ & & & & & \\
Negcog & .419 & $.651^{1}$ & & & & \\
Posaft & .366 & .156 & $.906^{1}$ & & & \\
Negaft & .182 & .228 & .208 & $.888^{1}$ & & \\
Intention & .267 & .122 & .311 & .139 & $.940^{1}$ & \\
Impulsiveness & .001 & .000 & .002 & .011 & .003 & $.657^{1}$ \\
\hline
\end{tabular}

Notes: POSCOG, NEGCOG=Positive, negative cognitive attitude, POSAFT,

NEGAFT $=$ Positive, negative affective attitude ${ }^{1}=$ AVE. 


\section{Results}

\subsection{Demographic information}

The distribution of female and male in the sample was equally balanced, as $51 \%$ of the respondents were male and $49 \%$ were female. Charleston and Beaufort attract middle age and older couples. Therefore, the median age was 39 . The respondents are highly educated, almost $75 \%$ of them possess college or above degree. With regards to income level, $66 \%$ of the respondents' yearly income is over $55,000 \$$. Table 3 displays respondent's demographic information.

\section{Table 3}

Demographic information

\begin{tabular}{l|r}
\hline $\mathrm{N}=340$ & $\%$ \\
\hline Gender & \\
Male & 51.2 \\
Female & 48.8 \\
\hline Relationship status & \\
Not married or engaged & 21.5 \\
Engaged & 2.3 \\
Married & 75.6 \\
\hline Age & \\
$18-24$ & 8.3 \\
$25-34$ & 23.1 \\
$35-44$ & 17.8 \\
$45-54$ & 20.4 \\
$55-64$ & 21.3 \\
$65-74$ & 8.0 \\
75 and over & 1.2 \\
\hline Highest level of education & \\
Less than high school & 0.9 \\
High school & 5.0 \\
Some college & 19.7 \\
College graduate & 44.7 \\
Master's degree & 22.9 \\
Ph.D. degree & 6.5 \\
\hline Individual income (annual) & \\
Under 25,000 & 10.6 \\
$25,000-54,999$ & 23.1 \\
$55,000-84,999$ & 21.0 \\
$85,000-114,999$ & 18.1 \\
$115,000-144,999$ & 7.7 \\
$145,000-174,999$ & 3.9 \\
$175,000-189,999$ & 2.7 \\
190,000 and more & 5.6 \\
\hline & \\
\hline
\end{tabular}

\subsection{Analysis of direct relationships}

After establishing the reliability and validity of the data, structural model was run to test the hypotheses. Results of the structural model showed that while the influence of positive cognitive $(\beta=.227)$ and affective $(\beta=-.408)$ attitude on intention was significant, the influence of negative cognitive and affective attitude was not. As a result, the respondents with higher positive cognitive and affective attitude have higher intention to eat oysters. Therefore, $\mathrm{H} 1$ and $\mathrm{H} 3$ are accepted, and $\mathrm{H} 2$ and $\mathrm{H} 4$ are rejected. $\mathrm{H} 5$ is supported as intention has a significant positive impact on behavior $(\beta=-.447)$. The respondents with higher intention to eat oysters, have a higher tendency to eat oysters during their trip. Figure 2 displays the unstandardized and standardized regression coefficients of significant direct relationships between variables. 
Figure 2

Regression coefficients of significant relationships

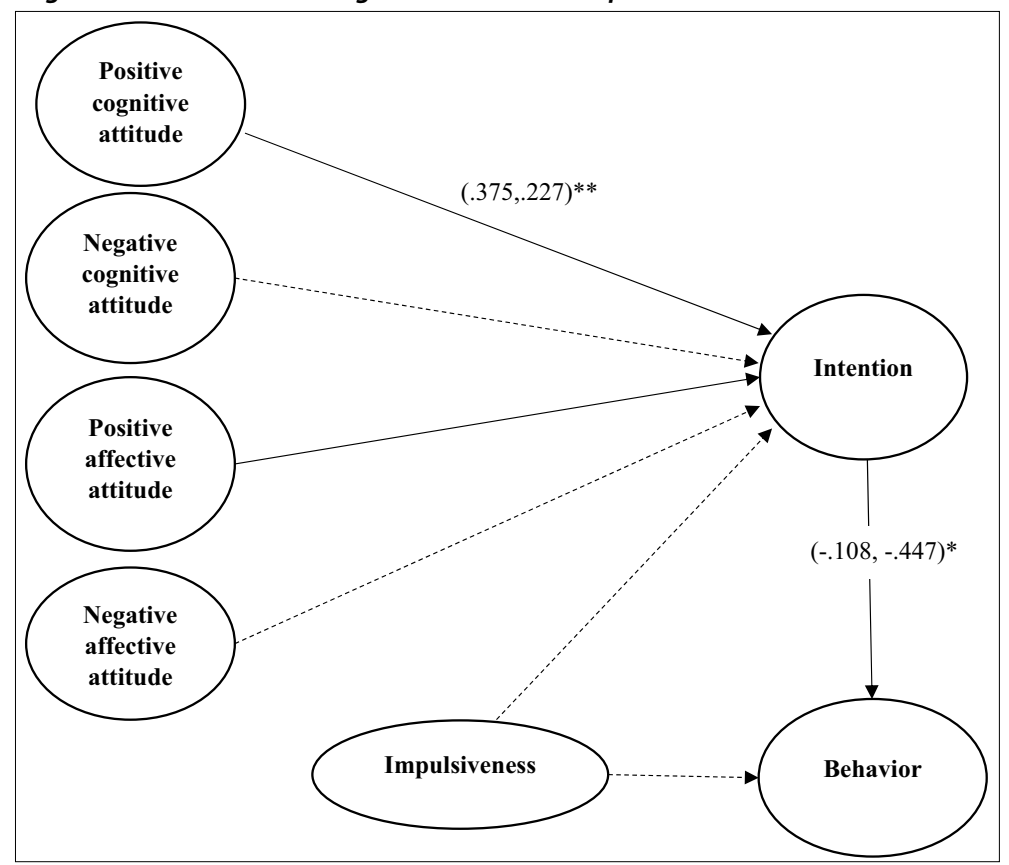

Notes: (Unstandardized, standardized), *p-value is significant at .05 level, ${ }^{* *}$ p-value is significant at .01 level. Dashed lines indicate no significant relationship between variables.

\subsection{Analysis of direct and indirect impact of impulsiveness}

While the influence of impulsiveness on intention and behavior is not significant, it significantly moderates the relationship between positive affective attitude and intention $(\beta=-.127)$. The relationship between positive affective attitude and intention to eat oysters is stronger for the people with high levels of impulsiveness. Figure 3 shows the regression coefficients of the significant indirect impact of impulsiveness. Smile slopes were calculated to visualize the indirect impact of impulsiveness on the relationship between positive affective attitude and intention. As it is seen on figure 4 slope of the relationship between positive attitude and intention is steeper for the people with high impulsiveness. $\mathrm{H} 6, \mathrm{H} 7$ and $\mathrm{H} 9$ are rejected and $\mathrm{H} 8$ is accepted.

Figure 3

Moderating impact of impulsiveness

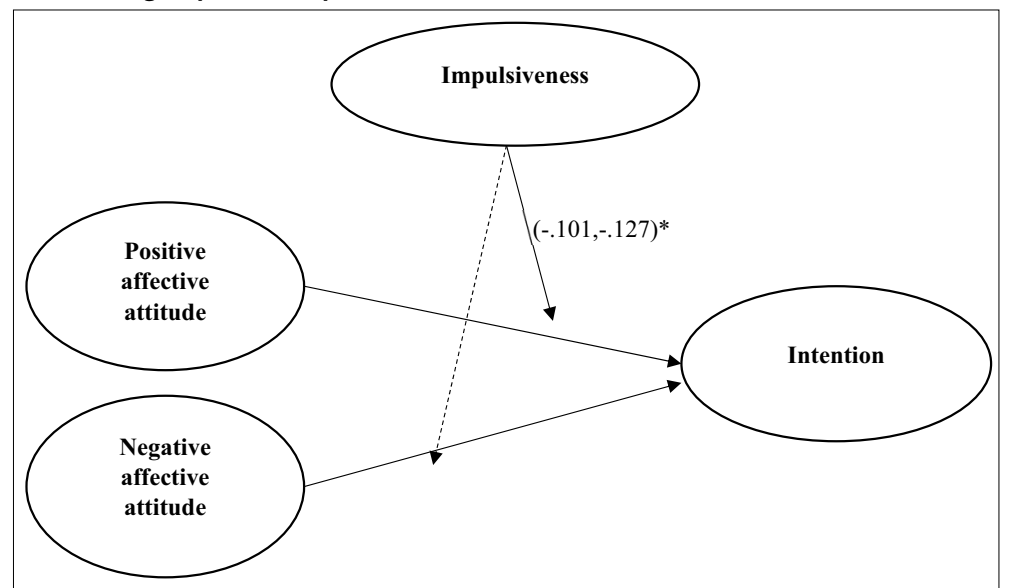

Notes: (Unstandardized, standardized), ${ }^{p} \mathrm{p}$-value is significant at .05 level. Dashed lines indicate no significant relationship between variables. 


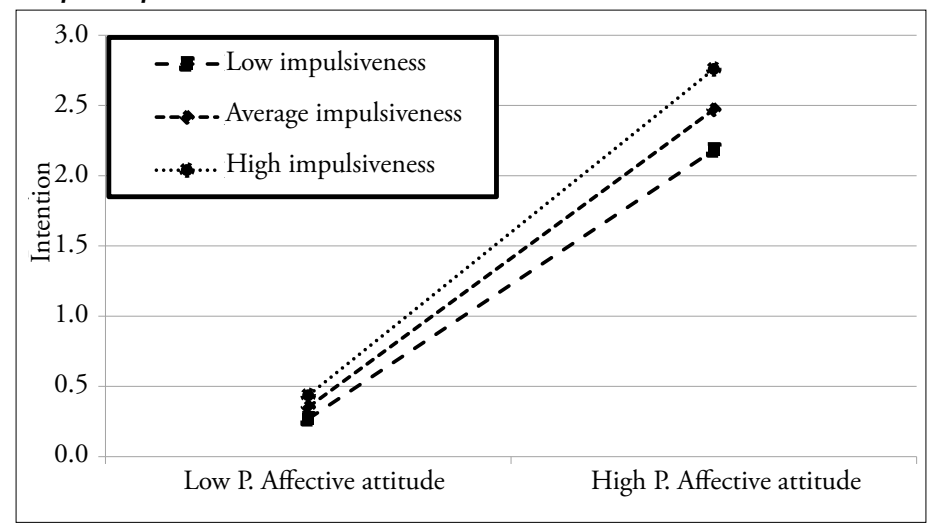

\section{Discussion and implications}

Results of the current study revealed that positive attitude (affective and cognitive) has a positive effect on intention to eat oysters which has a positive effect on behavior. On the other hand, negative attitude, both cognitive and affective, have no impact on intention. While impulsiveness has no direct significant effect on intention and behavior, it significantly moderates the relationship between positive affective attitude and intention.

Results are in accordance with the previous literature (Effendi et al., 2015; Bagozzi et al., 2000; Li et al., 2015; Tariq et al., 2019); people with a positive attitude towards oysters have higher intention to eat oysters during their vacation. And tourists who have a higher intention to eat oysters show a higher ratio of eating them during their trip. Therefore, the positive cognitive and affective attitude has an indirect influence on the food related behavior of tourists during vacation. While the impulsiveness does not influence intention and behavior directly, its moderating impact is significant. Previous research showed that both positive and negative feelings trigger impulsive buying (Youn \& Faber, 2000; Rook, 1987), however we observed the influence of impulsiveness only on positive attitude. The relationship between positive affective attitude and intention to eat oysters is stronger for people with high levels of impulsiveness. The people with a low level of impulsiveness will be more cautious about what they eat, and unlike people with high impulsiveness, their positive feelings will not influence their decisions. The influence of emotions on food choice was evidenced in previous research (Letarte et al., 1997; Winkielman et al., 2005). Usually, people with high impulsiveness base their decisions on emotions. The current research showed that impulsiveness has an impact on only positive emotions. Negative emotions such as stress are also influential on impulse purchases in daily life (Youn $\&$ Faber, 2000). Whereas in a travel environment people are usually in a positive mood.

The current study offers some practical implications for local food promoters and tourism planners in the region. The local food vendors may increase impulse purchases by adding value to their food products. Since only a positive attitude was significant on the intention to purchase oysters, the positioning of oysters as locally harvested food should be created in tourists' minds. Reinforcing a positive attitude should be the primary focus among tourism marketers in the area. This could be managed by dissembling information on locally harvested seafood on DMOs and NGOs' websites, social media, pamphlets, and brochures. A link to this website could be provided by Charleston and Beaufort webpages or more specific information on the regional fishing activities could be given. The information package could include the sustainable practices in the aquaculture industry in the region to gain consumer's trust. In this way, local restaurants and hotels would be willing to buy local seafood directly from producers and sell them under their brand name. This 
would create credibility for the product and contribute to the dining experience of tourists who will spread positive word of mouth through online blogs and social media. 'Single Lady' oysters, which are aquacultured, is one successful example of product positioning in the Charleston area (Lauvray, 2016)

It would be not realistic to advise Charleston and Beaufort tourism bureaus to base their marketing campaigns on the positioning of aquacultured seafood. However, eating fresh seafood is one of the main activities for tourists in coastal regions. By collaborating with the seafood producers in the region, an environment could be created for tourists to taste fresh local seafood. There are seafood festivals in the region where people can enjoy seafood. However, these events are held once a year, and demand could not be met due to a high number of visitors. More specialized small scale 'farm to fork' events may be more attractive to the tourists.

\section{Conclusions}

The current study attempted to incorporate impulsiveness to the TRA. The results of the study are useful to explain the food related behavior of tourists during vacation. The fact that the influence of impulsiveness is significant only on positive attitude during vacation, supports the argument that food related behavior during travel is not similar to the daily life. This study built upon the TRA to analyze factors influencing tourists' decisions regarding local food and empirically tested it among tourists visiting South Carolina. It could be further tested among tourist groups visiting different regions.

\section{Limitations and suggestions for future research}

The first limitation of this study is the fact that oysters were chosen as local food. Future studies could test the influence of impulsiveness on the intention to purchase a different kind of local food or other travel decisions. The impulsive buying behavior in decisions regarding travel within different financial ranges would be an area worth to study. The second limitation is the collection of data during travel. The measurement of actual behavior and its relationship with the intention could be managed by collecting the data after travel is over. Airports could be a good place to find tourists who have fresh memories of the vacation. The influence of positive and negative mood on the impulse purchase behavior during vacation could further be explored. An understanding of pleasure food consumption while travelling will be beneficial for tourism planners in the destinations (Fusté-Forné, 2019). Also the sampling method of the study was not strong enough. Purposive sampling and qualitative study for in-depth understanding of couple dynamics are recommended for future studies. The data was collected among Americans; the results reflect the American cultural norms. Future studies could be more reflective of diverse cultures.

\section{Acknowledgment:}

This paper was prepared by Clemson University as a result of work sponsored by the South Carolina Sea Grant Consortium with NOAA financial assistance number NA10OAR4170073. The statements, findings, conclusions, and recommendations are those of the author(s) and do not necessarily reflect the views of the South Carolina Sea Grant Consortium or NOAA.

\section{References}

Ahn, J., Lee, S.L. \& Kwon, J. (2020). Impulsive buying in hospitality and tourism journals. Annals of Tourism Research, Article 102764.

Ajzen, I. (1985). From intentions to actions: A theory of planned behavior. In J. Kuhl \& J. Beckmann (Eds.), Action control (pp. 11-39). Springer.

Bagozzi, R.P., Wong, N., Abe, S., \& Bergami, M. (2000). Cultural and situational contingencies and the theory of reasoned action: Application to fast food restaurant consumption. Journal of Consumer Psychology, 9(2), 97-106. 
Baloglu, S., \& Brinberg, D. (1997). Affective images of tourism destinations. Journal of Travel Research, 35(4), 11-15.

Beatty, S.E., \& Ferrell, M.E. (1998). Impulse buying: Modeling its precursors. Journal of Retailing, 74(2), $169-191$.

Beatty, S.E., \& Ferrell, M.E. (1998). Impulse buying: Modelling its precursors. Journal of Retailing, 74(2), 169-191.

Blanchard, C., Fisher, J., Sparling, P., Nehl, E., Rhodes, R., Courneya, K., \& Baker, F. (2008). Understanding physical activity behavior in African American and Caucasian college students: An application of the theory of planned behavior. Journal of American College Health, 56(4), 341-346.

Bredahl, L. (2001). Determinants of consumer attitudes and purchase intentions with regard to genetically modified food-results of a cross-national survey. Journal of Consumer Policy, 24(1), 23-61.

Chen, C.D., Ku, E.C., \& Yeh, C.C. (2019). Increasing rates of impulsive online shopping on tourism websites. Internet Research, 29(4) 900-920.

Chih, W.H., Wu, C.H.J., \& Li, H.J. (2012). The antecedents of consumer online buying impulsiveness on a travel website: Individual internal factor perspectives. Journal of Travel \& Tourism Marketing, 29(5), 430-443.

Chung, N., Song, H.G., \& Lee, H. (2017). Consumers' impulsive buying behavior of restaurant products in social commerce. International Journal of Contemporary Hospitality Management, 29(2), 709-731.

Coskun, G., Jodice, L., \& Moore D. (2019). A multi-level analysis of mixed-gender couple's food decisions in a tourism context. Journal of Hospitality and Tourism Insights, 2(2), 121-144.

Crites, S.L., Fabrigar, L.R., \& Petty, R.E. (1994). Measuring the affective and cognitive properties of attitudes: Conceptual and methodological issues. Personality and Social Psychology Bulletin, 20(6), 619-634.

Derbaix, C., \& Pham, M.T. (1991). Affective reactions to consumption situations: A pilot investigation. Journal of Economic Psychology, 12(2), 325-355.

Dittmar, H., Beattie, J., \& Friese, S. (1995). Gender identity and material symbols: Objects and decision considerations in impulse purchases. Journal of Economic Psychology, 16(3), 491-511.

Duarte, P., Raposo, M., \& Ferraz, M. (2013). Drivers of snack foods impulse buying behaviour among young consumers. British Food Journal, 115(9), 1233-1254.

Dubé, L., Cervellon, M.C., \& Jingyuan, H. (2003). Should consumer attitudes be reduced to their affective and cognitive bases? Validation of a hierarchical model. International Journal of Research in Marketing, 20(3), $259-272$.

Effendi, I., Ginting, A., Lubis, A.N., \& Fachruddin, K. (2015). Analysis of consumer behavior of organic food in North Sumatra Province, Indonesia. Journal of Business and Management, 4(1), 44-58.

Fishbein, M., \& Ajzen, I. (1975). Belief, attitude, intention, and behavior: An introduction to theory and research. Addison-Wesley Publishing Company.

Fornell, C., \& Larcker, D.F. (1981). Structural equation models with unobservable variables and measurement error: Algebra and statistics. Journal of Marketing Research, 18 (3), 39-50.

Fusté-Forné, F. (2019). Food for tourists: A need or a pleasure? Tourism: An International Interdisciplinary Journal, 67(1), 87-89.

Jodice, L.W., Norman, W.C., Davis, J., Coskun, G., \& Kang, S. (2015). Perceptions of marine aquaculture in coastal tourist destinations in the US Southeastern region: Final report. Clemson University-South Carolina Sea Grant. http://media.clemson.edu/cbshs/prtm/research/Mariculture.pdf

Jun, J., \& Arendt, S.W. (2016). Understanding healthy eating behaviors at casual dining restaurants using the extended theory of planned behavior. International Journal of Hospitality Management, 53, 106-115.

Kim, S. \& Yoon, Y. (2003). The hierarchical effects of affective and cognitive components on tourism destination image. Journal of Travel \& Tourism Marketing, 14(2), 1-22.

Kim, Y.G., Eves, A., \& Scarles, C. (2013). Empirical verification of a conceptual model of local food consumption at a tourist destination. International Journal of Hospitality Management, 33, 484-489.

Kim, Y.H., Goh, B.K., \& Yuan, J. (2010). Development of a multi-dimensional scale for measuring food tourist motivations. Journal of Quality Assurance in Hospitality \& Tourism, 11(1), 56-71.

Lauvray, C. (2016, September 30). Frank Roberts a passion for cultivating oysters. Beaufort Lifestyle. http://beaufortlifestyle.com/2016/09/30/frank-roberts-a-passion-for-cultivating-oysters/

Letarte, A., Dubé, L., \& Troche, V. (1997). Similarities and differences in affective and cognitive origins of food likings and dislikes. Appetite, 28(2), 115-129. 
Li, Z.F., Deng, S., \& Moutinho, L. (2015). The impact of experience activities on tourist impulse buying: An empirical study in China. Asia Pacific Journal of Tourism Research, 20(2), 191-209.

Lim, P.L., \& Yazdanifard, R. (2015). What internal and external factors influence impulsive buying behavior in online shopping? Global Journal of Management and Business Research, 15(5). https://journalofbusiness.org/index.php/GMBR/article/view/1703

Lovelock, B. (2004). Tourist-created attractions: The emergence of a unique form of tourist attraction in Southern New Zealand. Tourism Geographies, 6(4), 410-433.

Miao, L. (2011). Guilty pleasure or pleasurable guilt? Affective experience of impulse buying in hedonic-driven consumption. Journal of Hospitality \& Tourism Research, 35(1), 79-101.

Quan, S., \& Wang, N. (2004). Towards a structural model of the tourist experience: An illustration from food experiences in tourism. Tourism Management, 25(3), 297-305.

Robinson, R. \& Smith, C. (2002). Psychosocial and demographic variables associated with consumer intention to purchase sustainably produced foods as defined by the Midwest Food Alliance. Journal of Nutrition Education and Behavior, 34(6), 316-325.

Rook, D. W. (1987). The buying impulse. Journal of Consumer Research, 14(2), 189-199.

Rook, D.W., \& Fisher, R.J. (1995). Normative influences on impulsive buying behavior. Journal of Consumer Research, 22(3), 305-313.

Ryu, K., \& Han, H. (2010). Predicting tourists' intention to try local cuisine using a modified theory of reasoned action: The case of New Orleans. Journal of Travel \& Tourism Marketing, 27(5), 491-506.

Sohn, H.K., \& Lee, T.J. (2017). Tourists' impulse buying behavior at duty-free shops: The moderating effects of time pressure and shopping involvement. Journal of Travel \& Tourism Marketing, 34(3), 341-356.

Stern, H. (1962). The significance of impulse buying today. Journal of Marketing, 26(2), 59-62.

Su, C.S., \& Lu, P.H. (2018). A study of the factors influencing customers' impulse buying behavior in restaurants. Advances in Hospitality and Tourism Research, 6(1), 47-67.

Tariq, A., Wang, C., Akram, U., Tanveer, Y., \& Sohaib, M. (2019). Online impulse buying of organic food: Moderating role of social appeal and media richness. In J. Xu, S.E. Ahmed, F.L. Cooke, \& G. Duca (Eds.), Proceedings of the Thirteenth international conference on management science and engineering management (pp. 586-599). Springer.

Trendel, O., \& Werle, C.O. (2016). Distinguishing the affective and cognitive bases of implicit attitudes to improve prediction of food choices. Appetite, 104, 33-43.

Uehara, W., \& Assarut, N. (2020). Foreign food consumption as an extraordinary experience: A comparative study on the perceived value of Japanese and Thai consumers. Tourism: An International Interdisciplinary Journal, 68(2), 120-129.

Winkielman, P., Berridge, K.C., \& Wilbarger, J.L. (2005). Unconscious affective reactions to masked happy versus angry faces influence consumption behavior and judgments of value. Personality and Social Psychology Bulletin, 31(1), 121-135.

Youn, S., \& Faber, R.J. (2000). Impulse buying: Its relation to personality traits and cues. Advances in Consumer Research, 27, 179-185.

Žeželj, I., Milošević, J., Stojanović, Ž., \& Ognjanov, G. (2012). The motivational and informational basis of attitudes toward foods with health claims. Appetite, 59(3), 960-967.

Submitted: January 21, 2020

Revised: April 22, 2020

Revised: June 23, 2020

Accepted: July10, 2020

Refereed Anonymously 